\title{
PENGARUH SUHU TERHADAP LAJU KOROSI BAJA KARBON RENDAH DALAM MEDIA AIR LAUT
}

\author{
Ahmad Royani \\ Program Studi Teknik Mesin, Fakultas Teknik, Universitas Pamulang \\ dosen01589@unpam.ac.id
}

\begin{abstract}
The use of carbon steel in the construction of maritime and offshore infrastructure is very vulnerable to damage due to corrosion. To determine the effect of temperature on the corrosion rate of carbon steel, a study of corrosion was conducted using the electrochemical linear polarization by the Tafel method on seawater media. Tafel polarization is carried out at various temperatures by changing the electrode potential automatically. The results show that the corrosion rate of low carbon steel in seawater media at room temperature, $37^{\circ} \mathrm{C}$, and $50{ }^{\circ} \mathrm{C}$ is 5.54 mpy; $11.91 \mathrm{mpy}$, and $14.53 \mathrm{mpy}$, respectively. The increase in temperature of seawater media will cause an increase in the rate of the corrosion reaction and consequently the higher corrosion rate. In addition to the temperature solution, corrosion in seawater media is also affected by the content of dissolved oxygen, salinity, $\mathrm{pH}$, and total dissolved solids.
\end{abstract}

ABSTRAK
Penggunaan baja karbon dalam pembangunan infrastruktur kawasan maritim dan lepas pantai sangat rentan terhadap kerusakan akibat korosi. Untuk mengetahui pengaruh suhu terhadap laju korosi dari baja karbon tersebut, maka dilakukan pengkajian korosi dengan metode Tafel polarisasi linear secara elektrokimia pada media air laut. Ekstraspolasi Tafel dilakukan pada berbagai suhu dengan mengubah potensial elektroda secara otomatis. Hasil laju korsi baja karbon rendah pada media air laut pada suhu ruang, $37{ }^{\circ} \mathrm{C}$ dan $50{ }^{\circ} \mathrm{C}$ masing-masing sebesar 5,54 mpy; 11,91mpy dan 14,53 mpy. Kenaikan suhu akan menyebabkan bertambahnya kecepatan reaksi dan mengakibatkan laju korosi menjadi meningkat. Selain faktor suhu larutan, korosi di media air laut juga dipengaruhi oleh kandungan oksigen terlarut, salinitas, $\mathrm{pH}$ dan total padatan terlarut.

Kata kunci: air laut; baja karbon, korosi; polarisasi; suhu.

\section{PENDAHULUAN}

Indonesia merupakan negara maritim dan kepulauan yang memiliki kawasan perairan dan lepas pantai yang luas. Fasilitas lepas pantai sangat rentan terhadap kerusakan korosi di lingkungan Laut dan sering mengakibatkan konsekuensi serius yang dapat menyebabkan beberapa kecelakaan seperti kerusakan struktur jembatan, keruntuhan struktur maritim, kegagalan pipa akibat korosi, struktur pelabuhan runtuh atau tidak dapat digunakan, penimbunan pintu air dan kecelakaan lainnya. Lingkungan korosi laut biasanya dibagi menjadi lima area korosi: zona atmosfer, zona percikan, zona rentang pasang surut, zona perendaman penuh dan area lumpur laut (John and Peter,1995). Korosi material logam berbeda-beda tergantung faktor lingkungan dan zona logam tersebut terekspos. Zona percikan, zona pasang surut dan zona pencelupan penuh adalah area yang sangat serius di mana struktur logam mengalami korosi (Do and Roy, 1994). Ketahanan korosi dari suatu logam dalam air laut tergantung pada status laut dan status material, status laut terutama meliputi salinitas, suhu, oksigen terlarut, nilai pH, laut biofouling (Toloei et al., 2013 \& Yuwei, L., et al., 2019). Di mana salinitas merupakan faktor utama, status material terutama mencakup komposisi kimia, struktur, keadaan permukaan (Zakowski, et al., 2013).
Laju korosi dalam air laut adalah fungsi dari sejumlah besar faktor yang saling tergantung. Salah satu faktor penting dalam laju korosi logam di air laut adalah suhu air mengingat negara Indonesia memiliki musim panas dan musim hujan yang dapat menyebabkan perbedaan suhu permukaan air laut. Suhu air telah lama dikenal sebagai faktor penting yang mempengaruhi laju korosi, sebagian besar didasarkan pada pertimbangan teoretis dan hasil penelitian laboratorium (Umeozokwere, et al., 2016). Suhu larutan ini mempengaruhi banyak terhadap kinetika korosi (ion), konsentrasi oksigen, dan difusi (Sekunowo, et al., 2013). Telah banyak dilakukan studi tentang performa korosi dilingkungan air laut (Sekunowo, et al., 2013; Refait, et al., 2018 \& Utomo, S., 2015).

Studi korosi pada air laut secara perendaman, terdapat hasil yang menunjukkan bahwa laju korosi baja karbon pada awal proses cenderung meningkat dengan cepat seiring dengan waktu ekspos (Sekunowo, et al., 2013), kemudian laju korosi menjadi laju korosi linier ketika kinetika reaksi dikendalikan oleh laju reaksi (Refait, et al., 2018). Peristiwa ini disebabkan oleh terbentuknya lapisan tipis produk korosi yang menghambat pasokan oksigen ke permukaan logam (Roberge, P. R., 2008). Secara umum, ketika kinetika proses korosi dikendalikan oleh reaksi kimia, maka laju 


\section{JURNAL SIMETRIK VOL.10, NO.2, DESEMBER 2020}

korosi meningkat singnifikan untuk setiap kenaikan suhu $10{ }^{\circ} \mathrm{C}$. Sebaliknya jika proses korosi dikendalikan oleh proses difusi (seperti akibat ketersediaan oksigen yang terbatas), maka diperlukan kenaikan suhu hingga $30{ }^{\circ} \mathrm{C}$ untuk meninggkatkan laju korosi (Uhliq, H. H., and Revie, R. W., 2008).

Pada penelitian ini dijelaskan pengaruh suhu larutan terhadap laju korosi pada material baja karbon rendah didalam media air laut. Variabel suhu larutan yang digunakan adalah suhu ruang, $37{ }^{\circ} \mathrm{C}$ dan $50{ }^{\circ} \mathrm{C}$. Selain pengaruh suhu larutan, pembahasan terkait korelasi antara parameter air laut dengan laju korosi juga turut dibahas.

\section{TINJAUAN PUSTAKA \\ 2.1 Baja Karbon}

Baja karbon merupakan baja yang banyak diaplikasikan dalam pembangunan infrastruktur karena memiliki sifat mekanik yang baik. Baja karbon atau dikenal dengan baja plan carbon paling umum digunakan untuk berbagai aplikasi karena harganya relatif rendah. Salah satu dari baja karbon adalah baja karbon rendah yang mengandung kira-kira 0,05-0,25\% karbon sehingga mudah ditempa dan ulet (Dwivedi, et al., 2017). Baja karbon rendah memiliki kekuatan tarik yang relatif rendah tetapi daktilitas tinggi, kemampuan las dan kemampuan mesin (Olaseinde, et al., 2016). Keunggulan lain dari baja karbon rendah adalah murah dan mudah dibentuk, kekerasan permukaan dapat ditingkatkan melalui karburisasi (Olaseinde, et al., 2016). Namun, material baja karbon diproduksi bukan diperuntukan untuk tujuan tahan terhadap korosi, tetapi penggunaan dari baja tersebut seringkali diaplikasikan pada lingkungan yang korosif.

\subsection{Korosi dan Jenis Korosi}

Korosi didefinisikan sebagai degredasi suatu material atau sifat-sifatnya karena interaksi dengan lingkungannya (Revie, R.W and Uhlig, H.H., 2008). Kecenderungan logam terkorosi tergantung pada struktur butiran logam, komposisi kimia paduan dan suhu deformasi permukaan logam selama fabrikasi (Roberge, P.R., 2008). Pencegahan korosi akan lebih praktis dan ekonomis daripada menghilangkan sepenuhnya. Mengingat bahwa lingkungan memainkan peran penting dalam korosi, mekanisme korosi dapat beragam seperti lingkungan tempat suatu logam terekspos dan karenanya mungkin sangat rumit untuk dipahami. Faktor-faktor yang menyebabkan korosi termasuk reaktivitas logam, keberadaan pengotor, kandungan gas udara, kelembaban, gas seperti sulfur dioksida dan karbon dioksida, dan adanya elektrolit (Revie, R.W and Uhlig, H.H., 2008). Berbagai jenis korosi tergantung pada lingkungan di sekitar material, jenis material, atau reaksi kimia. Jenis-jenis korosi terdiri dari korosi merata, korosi galvanik atau bimetalik, korosi sumuran, stress corrosion cracking (SCC), korosi fatik, korosi batas butir, korosi celah dan korosi erosi (Revie, R.W and Uhlig, H.H., 2008).

Salah satu faktor yang mempengaruhi terbentuknya korosi pada lingkungan air laut adalah kandungan air laut itu sendiri. Parameter-parameter air laut meliputi kecepatan arus, konduktivitas dan jumlah padatan terlarut, $\mathrm{pH}$ air dan temperature.

\subsection{Kecepatan aliran}

Kecepatan aliran sangat tinggi dapat menyebabkan korosi erosi pada permukaan logam (Qingwei, et al., 2017). Kecepatan fluida aliran rendah dapat menyebabkan jenis korosi under deposit (Qingwei, et al., 2017).

\subsection{Konduktivitas dan Total Padatan Terlarut (TDS)}

Konduktivitas adalah ukuran kemampuan air untuk menghantarkan arus listrik dan mengindikasikan jumlah padatan terlarut (TDS) dalam air. Air suling murni memiliki konduktivitas sangat rendah dan air laut memiliki konduktivitas yang tinggi (Roberge, P.R., 2008).

\section{5 pH Larutan}

$\mathrm{pH}$ adalah ukuran seberapa asam atau basa air. $\mathrm{pH}$ kurang dari 7 menunjukkan keasaman, sedangkan $\mathrm{pH}$ lebih besar dari 7 menunjukkan air bersifat basa. Secara umum, ketika $\mathrm{pH}$ lingkungan asam, kecenderungan terjadinya korosi meningkat dan sebaliknya ketika $\mathrm{pH}$ lingkungan alkali, kecenderungan terjadinya deposit meningkat (Nuha, H. J. H., 2008).

\subsection{Suhu Larutan}

Suhu larutan sangat mempengaruhi laju korosi. Dalam media aqueous, korosi baja karbon yang diakibatkan oleh oksigen sangat dipengaruhi suhu. Dalam system terbuka, semakin naik suhu, kelarutan oksigen dalam media aqueous semakin menurun karena oksigen dapat dibebaskan, sebaliknya dalam sistem tertutup oksigen tidak dibebaskan, sehingga semakin naik suhu, laju korosi semakin meningkat (Uhlig, H.H., 2008). Semakin naik suhu, viskositas dari media aqueous semakin turun sehingga memudahkan oksigen terdifusi ke permukaan logam. Hal ini akan meningkatkan laju korosi baja karena jumlah oksigen yang terlarut sebagian besar dikonsumsi dalam proses reduksi pada daerah katoda (Sundjono and Saefudin, 2014).

\section{METODOLOGI}

Material yang digunakan pada penelitian ini adalah baja karbon rendah yang ada dipasaran dengan komposisi kimia pada Tabel 1. Media larutan yang digunakan berupa air laut yang diambil dari pantai daerah Jakarta.

Tabel 1. Komposisi Kimia Spesimen Baja Karbon

Komposisi kimia spesimen baja karbon (\% berat)

\begin{tabular}{|c|c|c|c|c|c|c|}
\hline $\mathrm{Fe}$ & $\mathrm{C}$ & $\mathrm{Ni}$ & $\mathrm{Mn}$ & $\mathrm{Si}$ & $\mathrm{S}$ & $\mathrm{P}$ \\
\hline Sisa & 0,1911 & 0,1262 & 0,7577 & 0,1138 & 0,0258 & 0,0132 \\
\hline
\end{tabular}

Sumber: Royani, 2019. 


\section{JURNAL SIMETRIK VOL.10, NO.2, DESEMBER 2020}

Luas permukaan logam yang digunakan pada pengujian Tafel polarisasi ini sebesar $10 \mathrm{~mm} \times 10 \mathrm{~mm}$ $=100 \mathrm{~mm}^{2}$. Pembersihan kotoran pada permukaan logam sebelum pengujian korosi dilakukan menggunakan kertas ampelas grit 400 serta dilanjutkan dengan pembilasan menggunakan larutan etanol. Elektroda yang digunakan terdiri dari tiga elekroda yaitu elektoda kerja berupa logam baja karbon, elektroda counter berupa platina dan elektroda referensi berupa Calomel.

Pengujian korosi spesimen baja karbon dilakukan secara elektrokimia dengan metode Tafel polarisasi. Tafel pada berbagai suhu dengan mengubah potensial elektroda secara otomatis dari $-250 \mathrm{mV}$ sampai +250 $\mathrm{mV}$ vs SCE pada potensi sirkuit terbuka (OCP) dengan laju pemindaian $1,0 \mathrm{mVs}^{-1}$. Arus densitas korosi $\left(I_{C O R R}\right)$ dan $\mathrm{E}_{\text {corr }}$ diperoleh dari ekstrapolasi grafik Tafel pada titik persimpangan kurva anodik dan katodik menggunakan E-Chem software. Laju korosi logam selanjutnya dapat dihitung dengan Persamaan (1).

$$
\mathrm{CR}=0.129 \frac{\mathrm{i}_{\text {corr }} \cdot \mathrm{M}}{\mathrm{D}}
$$

\section{HASIL DAN PEMBAHASAN}

Kurva Tafel hasil polarisasi baja karbon pada berbagai suhu dalam media air laut di sajikan pada Gambar 1. Terlihat jelas bahwa laju korosi semakin tinggi dengan kenaikan suhu larutan.

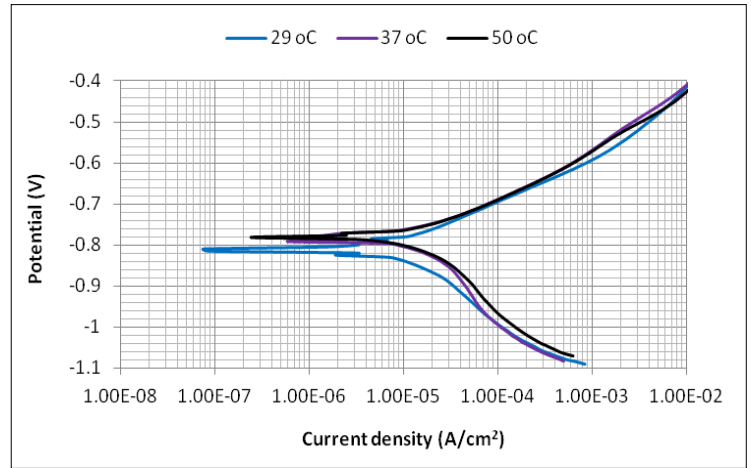

Sumber: Royani, 2019

\section{Gambar 1. Tafel Polarisasi Baja Karbon Pada Berbagai Suhu Dalam Media Air Laut}

Pada umumnya mekanisme peristiwa proses korosi sebuah logam di lingkungan air berawal dari logam yang teroksidasi di dalam larutan dan melepaskan elektron ( $\left.\mathrm{e}^{-}\right)$untuk menghasilkan ion logam bermuatan positif $\left(\mathrm{M}^{+}\right)$. Larutan akan bertindak sebagai katoda dengan reaksi yang umum terjadi adalah pelepasan $\mathrm{H}_{2}$ dan reduksi $\mathrm{O}_{2}$, akibat $\mathrm{H}^{+}$dan $\mathrm{H}_{2} \mathrm{O}$ yang tereduksi. Reaksi tersebut terjadi pada bagian permukaan logam, sehingga menyebabkan pengelupasan akibat terjadinya pelarutan logam ke dalam larutan secara terus menuerus (Moller, et al., 2006).

Secara termodinamika, peristiwa terjadinya proses korosi merupakan kecenderungan normal suatu logam untuk kembali pada kondisi alaminya (bentuk oksida), atau kebentuk yang lebih stabil. Pada suhu rendah dan dalam lingkungan basa, proses korosi terjadi melalui mekanisme reaksi elektrokimia yang membentuk reaksi reduksi dan reaksi oksidasi. Reaksi elektrokimia didefinisikan sebagai reaksi kimia yang melibatkan perpindahan electron menurut anoda (-) ke katoda (+) dalam larutan elektrolit (Refait, et al., 2018).

\subsection{Pengaruh Suhu}

Hasil ekstrapolasi dari grafik Tafel polarisasi (Gambar 1) pada berbagai suhu menghasilkan nilai laju korosi seperti di dalam grafik pada Gambar 2. Suhu merupakan faktor penting dalam proses terjadinya korosi, di mana Kenaikan suhu akan menyebabkan bertambahnya kecepatan reaksi korosi (Mardhani, I. and Harmami, 2013). Hal ini karena terjadi penambahan energi kinetik dari partikel-partikel yang bereaksi akibat peningkatan suhu larutan sehingga melebihi besarnya energi aktivasi. Kecepatan laju korosi semakin tinggi jika harga energi kinetika lebih besar dari harga energi aktivasinya (Melchers, R. E., 2002).

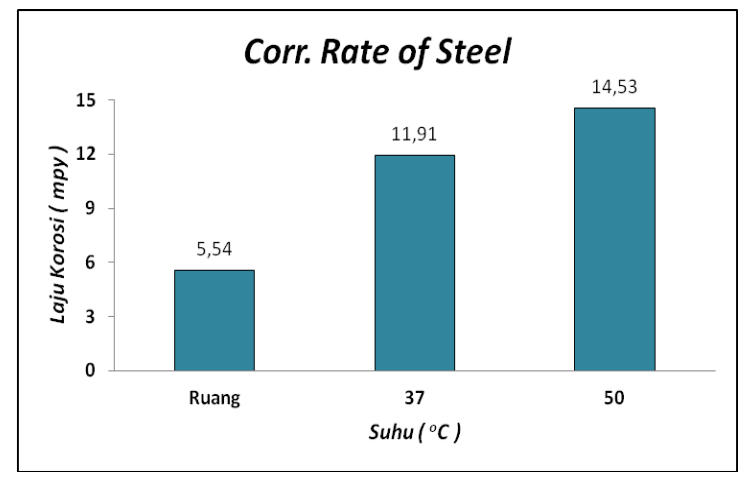

Sumber: Royani, 2019.

\section{Gambar 2. Hasil Laju Korosi Versus Suhu}

Suhu dapat mempercepat semua proses yang terlibat dalam peristiwa korosi. Peningkatan laju korosi pada suhu yang lebih tinggi karena terjadi peningkatan difusi oksigen pada permukaan logam. Nilai maksimum laju korosi biasanya terlihat antara 50 dan $80{ }^{\circ} \mathrm{C}$ tergantung pada kimia air dan kondisi proses (Uhliq, H. H., and Revie, R. W., 2008).

Pengaruh suhu pada laju korosi logam dalam air laut terlihat cukup rumit. perubahan suhu mempengaruhi komposisi kimia dan sifat fisik air laut, sifat produk korosi, perilaku elektrokimia logam itu sendiri dan tingkat kelarutan dan difusi oksigen terlarut.

\subsection{Pengaruh Kualitas Air}

Air laut merupakan perairan dengan sistem kimia yang kompleks yang dipengaruhi oleh berbagai faktor lingkungan. Parameter air laut yang paling penting dari sudut pandang korosi adalah salinitas, $\mathrm{pH}$, konsentrasi oksigen terlarut, suhu, kecepatan dan jenis spesies biologis (John and Peter,1995). Hasil pengukuran parameter media air laut di sajikan dalam Gambar 3 sampai dengan Gambar 6 . 


\section{JURNAL SIMETRIK VOL.10, NO.2, DESEMBER 2020}

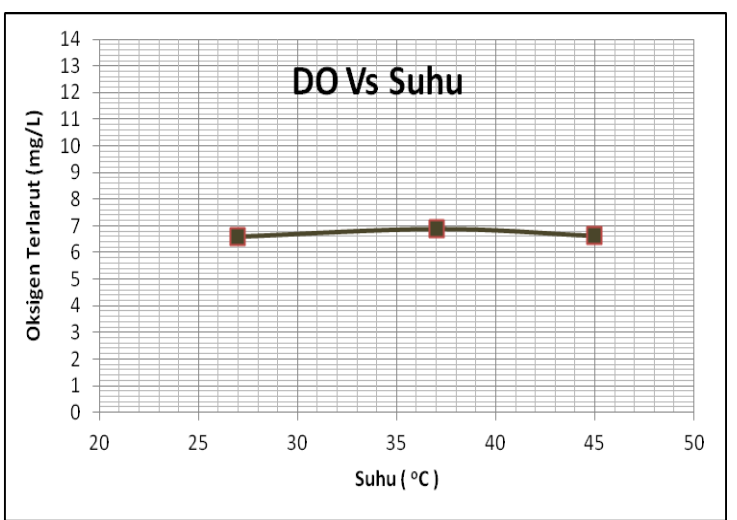

Sumber: Royani, 2019.

\section{Gambar 3. Kandungan Oksigen Terlarut Versus Suhu}

Korosi logam dalam larutan berair dikenal sebagai proses elektrokimia. Ini berarti bahwa reaksi korosi dapat dibagi menjadi oksidasi dan reaksi reduksi yang melibatkan transfer elektron dan terdapat ion penghantar dalam larutan. Reaksi proses terjadinya korosi pada logam besi di dalam air laut sesuai dengan persamaan reaksi:

Reaksi oksidasi (di daerah anodik):

$\mathrm{Fe} \rightarrow \mathrm{Fe}^{2+}+2 \mathrm{e}^{-}$

Reaksi reduksi (di daerah katodik):

$\mathrm{H}_{2} \mathrm{O}+1 / 2 \mathrm{O}_{2}+2 \mathrm{e}^{-} \rightarrow 2 \mathrm{OH}^{-}$

Reaksi keseluruhan dari reaksi anodik dan katodik adalah:

$\mathrm{Fe}+\mathrm{H}_{2} \mathrm{O}+1 / 2 \mathrm{O}_{2} \rightarrow \mathrm{Fe}^{2+}+2 \mathrm{OH}$

Kemudian ion $\mathrm{Fe}^{2+}$ bereaksi dengan $\mathrm{OH}$ membentuk besi hidroksida sesuai dengan persamaan:

$$
\mathrm{Fe}^{2+}+2 \mathrm{OH}^{-} \rightarrow \mathrm{Fe}(\mathrm{OH})_{2}
$$

Selanjutnya mengalami oksidasi lebih lanjut sesuai dengan persamaan reaksi:

$$
2 \mathrm{Fe}(\mathrm{OH})_{2}+1 / 2 \mathrm{O}_{2} \rightarrow \mathrm{Fe}_{2} \mathrm{O}_{3} \cdot \mathrm{H}_{2} \mathrm{O}+\mathrm{H}_{2} \mathrm{O}
$$

Dari sudut pandang termodinamika, reaksi ini dapat dan akan terjadi. Namun, laju reaksi ini ditentukan oleh kinetika sistem. Ini berarti bahwa laju keseluruhan proses korosi dikendalikan oleh langkah paling lambat yang dalam hal ini adalah reaksi reduksi. Dalam larutan netral atau mendekati netral $(\mathrm{pH} 6$ hingga $\mathrm{pH}$ 9) pada suhu kamar, laju langkah reduksi sangat lambat karena konsentrasi ion hidrogen yang rendah (Roberge, P. R., 2008 dan Royani, A. et al., 2019).

Ketika oksigen terlarut hadir, reaksi reduksi yang terjadi pada area katodik berlangsung pada tingkat yang jauh lebih cepat daripada tanpa adanya oksigen (Ismail, A. and Adan, N. H., 2014). Namun, agar oksigen terlarut bereaksi, ia harus mencapai permukaan logam dan ini dicapai dengan difusi melalui larutan. Dengan demikian laju korosi dibatasi oleh laju difusi oksigen terlarut. Karena laju difusi sebanding dengan konsentrasi oksigen terlarut mengikuti bahwa laju korosi juga sebanding dengan konsentrasi oksigen terlarut.

Uhliq, H. H., and Revie, R. W. (2008) mempelajari pengaruh konsentrasi oksigen pada korosi baja ringan dalam air suling yang bergerak perlahan dan dalam air yang mengandung 165 ppm kalsium klorida, pada suhu $25{ }^{\circ} \mathrm{C}$. Untuk larutan kalsium klorida, laju korosi ditemukan sebagai fungsi linier konsentrasi oksigen terlarut dalam kisaran 0 hingga 6 ml oksigen / liter (air jenuh udara). Untuk air suling, laju korosi juga ditemukan meningkat dengan konsentrasi oksigen terlarut meskipun laju korosi agak lebih rendah daripada dalam larutan kalsium klorida. Dengan tidak adanya oksigen terlarut dapat diabaikan dalam kedua media larutan tersebut (Uhliq, H. H., and Revie, R. W., 2008).

Parameter kualitas air yang mempengaruhi laju korosi selain oksigen terlarut adalah total padatan terlarut. Total padatan terlarut (TDS) digunakan untuk menggambarkan garam anorganik dan sejumlah kecil bahan organik yang ada dalam air. Konstituen vital biasanya kalsium, magnesium, natrium, kation kalium, hidrogen karbonat, kalium karbonat, klorida, sulfat, dan anion nitrat.

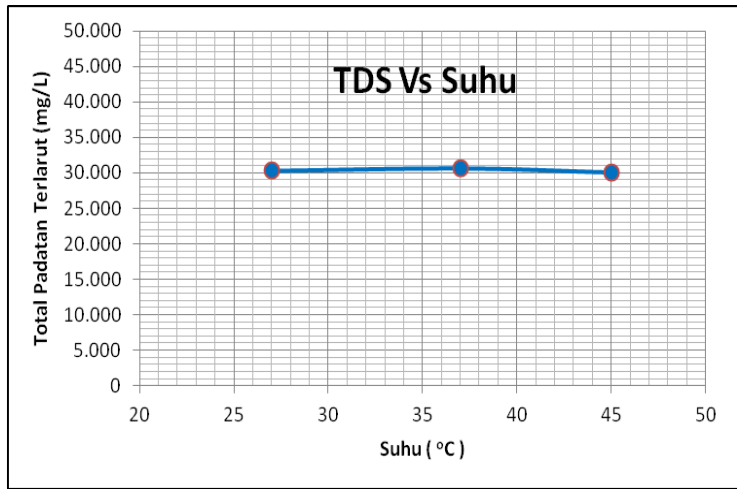

Sumber: Royani, 2019.

\section{Gambar 4. Total Padatan Terlarut Versus Suhu}

TDS di dalam kandungan air dapat berasal dari sumber alami, air limbah industri atau air limbah lainnya. Padatan terlarut dapat dimasukkan melalui bahan anorganik seperti batu dan udara yang mungkin memiliki jejak nitrogen, kalsium bikarbonat, fosfor besi, belerang, dan mineral lainnya. Total padatan terlarut (TDS) biasanya rendah untuk sumber air tawar yakni kurang dari 500 ppm (Roberge, P. R., 2008). Air deionisasi memiliki konduktivitas yang sangat rendah, sekitar $0,06 \mu \mathrm{S} / \mathrm{cm}$. Air laut dan air payau (campuran tawar dan air laut) masing-masing mengandung 500 30.000 dan 30-40.000 ppm TDS.

Pada larutan dengan nilai TDS tinggi cenderung memiliki laju korosi yang tinggi jika dibandingkan dengan larutan dengan TDS rendah. Hal ini berkaitan dengan pergerakan ion-ion yang jauh lebih banyak sehingga menyebabkan konduktivitas dari larutan tersebut meningkat (Phyllis, K. et al., 2007). Nilai pengukuran TDS pada berbagai suhu larutan di sajikkan dalam grafik pada Gambar 4. 


\section{JURNAL SIMETRIK VOL.10, NO.2, DESEMBER 2020}

Selain DO dan TDS, parameter kualitas air yang berdampak pada laju korosi terutama di lingkungan air laut adalah salinitas. Salinitas dapat sangat mempengaruhi karakteristik elektrolitik dan korosif air laut. Salinitas biasanya dihitung dari kadar klorida yang diukur atau konduktivitas listrik (Roberge, P. R., 2008). Ion klorida dapat meningkatkan kerusakan film pasif pada logam (Zakowski, et al., 2013). Salinitas di perairan laut dalam berkisar antara 34,5 dan 35ppt (Uhliq, H. H., and Revie, R. W., 2008). Salinitas di perairan dangkal juga lebih bervariasi daripada di laut dalam karena input air tawar dari sungai. Gambar 5 memberikan data hasil pengukuran salinitas versus suhu untuk media air laut yang digunakan.

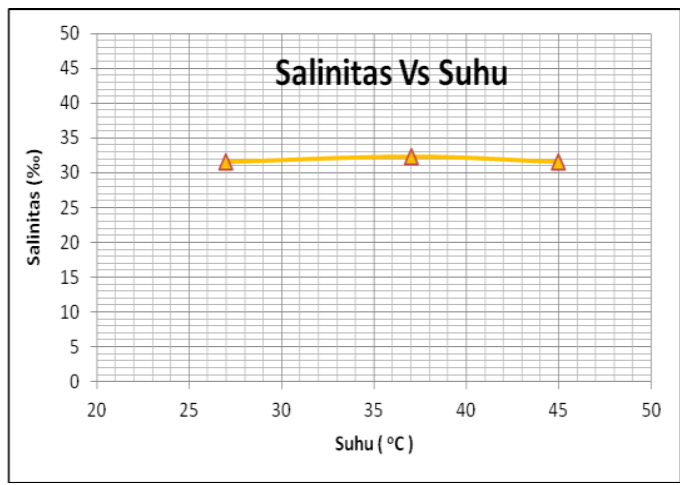

Sumber: Royani, 2019.

\section{Gambar 5. Salinitas Versus Suhu}

Parameter kualitas air lainnya yang juga berpengaruh terhadaplaju korosi adalah derajat keasaman atau biasa dikenal dengan nilai $\mathrm{pH}$. $\mathrm{PH}$ air merupakan parameter penting dalam menentukan korosifitas air Karena dapat mempengaruhi tingkat korosi logam. PH di lingkungan air laut dipengaruhi oleh aktivitas biologis, seperti pembusukan atau bahan organik dan aktivitas fotosintesis fitoplankton (Toloei et al., 2013). Sebagai akibatnya, dapat terjadi perubahan musiman pada $\mathrm{pH}$ di lingkungan dasar perairan yang dangkal. Selama musim panas, dengan dekomposisi atau bahan organik dan peningkatan aktivitas fauna, lebih banyak karbon dioksida dihasilkan, yang dapat menghasilkan kondisi yang sedikit asam. Namun, kondisi ini tidak stabil, dan $\mathrm{pH}$ menjadi basa ketika respirasi biologis berkurang.

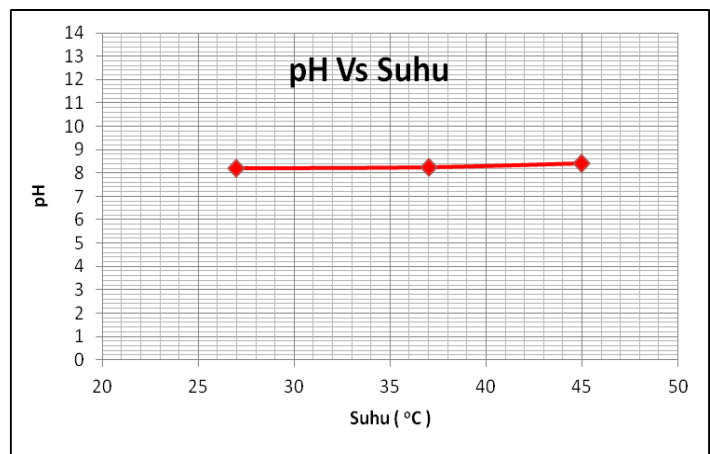

Sumber: Royani, 2019.

Gambar 6. pH Larutan Versus Suhu
Hasil pengukuran $\mathrm{pH}$ air laut pada berbagai suhu di sajikan pada Gambar 6. Hasil pengukuran nilai $\mathrm{pH}$ relatif sama sehingga pengaruhnya terhadap laju korosi pada spesimen baja tidak terlihat. Pada prinsipnya laju korosi akan semakain tinggi jika nilai $\mathrm{pH}$ larutan semakin rendah (Nuha, H. J. H., 2008). Laju korosi relatif konstan pada rentang nilai $\mathrm{pH}$ antara sekitar 6 dan 8 (Toloei et al., 2013).

\section{PENUTUP}

\subsection{Kesimpulan}

Laju korosi baja karbon rendah dalam media air laut dipengaruhi banyak faktor. Salah satu parameter yang mempengaruhi laju korosi adalah suhu lingkungan sikitar tempat logam terekspos. Kenaikan suhu dapat menyebabkan meningkatnya proses reaksi korosi sehingga laju korosi pada baja karbon semakin tinggi. Hasil laju korsi baja karbon rendah pada media air laut pada suhu ruang, $37{ }^{\circ} \mathrm{C}$ dan $50{ }^{\circ} \mathrm{C}$ masingmasing sebesar 5,54 mpy; 11,91 mpy dan 14,53 mpy. Parameter lingkungan air laut lainnya yang bedampak terhadap laju korosi adalah salinitas, $\mathrm{pH}$, oksigen terlarut dan total padatan terlarut.

\subsection{Saran}

Sangat penting dalam menjaga suhu larutan agar tetap konstan dan perlu dilakukan variasi arus/kecepatan fludia supaya mensimulasikan zona percikan yang merupakan daerah kritis dalam lingkungan air laut.

\section{DAFTAR PUSTAKA}

Do, K. H., and Roy, S. K. 1994. "Corrosion of Steel in Tropical Sea Water". British Corrosion Journal, $29,3,233-236$

Dwivedi, D., Lepkov, K., and Becker, T. 2017. "Carbon Steel Corrosion: A Review of Key Surface Properties and Characterization Methods". The Royal Society of Chemistry Advance, 7, 4580 4610.

John. H. H., and Peter Soo. (1995). Corrosion of Barrier Materials in Seawater Environments. New York: Environmental and Waste Technology Center.

Ismail, A., and Adan, N. H. 2014. "Effect of Oxygen Concentration on Corrosion Rate of Carbon Steel in Seawater". American Journal of Engineering Research (AJER), 3, 1, pp. 64-67.

Mardhani, I., and Harmami. 2013. "Pengaruh Suhu Terhadap Korosi Baja SS 304 dalam Media 1 M $\mathrm{HCl}$ dengan Adanya Inhibitor Kinina". Jurnal Sains dan Seni Pomits, 2, 2, 76-78.

Melchers, R. E. 2002. "Effect of Temperature on The Marine Immersion Corrosion of Carbon Steels". Corrosion, 58, 9, 768-782.

Moller, H., Boshoff, E. T., and Froneman, H. 2006. "The Corrosion Behaviour of A Low Carbon Steel in Natural and Synthetic Seawaters". The Journal of The South African Institute of Mining and Metallurgy, 106, 585-592. 


\section{JURNAL SIMETRIK VOL.10, NO.2, DESEMBER 2020}

Nuha, H. J. H. 2008. "Study The Effect of pH and TDS on The Corrosion Rate of Carbon Steel". Basrah Journal For Engineering Science, 133-14.

Olaseinde, O. A., Folorunsho, D. O., and Olaniran, O. 2016. "Heat Treatment and Corrosion Behaviour of Selected Steels in 3.5 M Sodium Chloride". American Journal of Engineering Research (AJER), 5, 5, 231-237.

Phyllis, K., Weber-Scannell, and Lawrence, K. D. 2007. "Effects of Total Dissolved Solids on Aquatic Organisms: A Review of Literature and Recommendation for Salmonid Species". American Journal of Environmental Sciences, 3, $1,1-6$.

Qingwei, N., Zili, L., Gan, C. and Bingying, W. 2017. "Effect of flow rate on the corrosion behavior of N80 steel in simulated oil field environment containing $\mathrm{CO}_{2}$ and HAc", Int. J. Electrochem. Sci., 12, pp. 10279-10290.

Refait, P. H., Grolleau, A. M., M. Jeannin, E. F., and Sabot, R. 2018. "Corrosion of Mild Steel at The Seawater/Sediments Interface: Mechanisms and Kinetics”. Corrosion Science, 130, 76-84.

Roberge, P. R. (2008). Corrosion Engineering: Principles and Practice. New York: McGrawHill.

Royani, A., Prifiharni, S., Priyotomo, G., Triwardono, J. and Sundjono, 2019, Performa Korosi Baja Karbon Pada Uji Simulasi Pipa Untuk Sistem Saluran Air Pendingin. Metalurgi, 34(2), pp. 4960.

Royani, A., Prifiharni, S., Priyotomo, G., Triwardono, J. and Sundjono, 2019, Corrosion of carbon steel in synthetic freshwater for water distribution systems, in IOP Conf. Ser.: Earth Environ. Sci. 399 012089, Indonesia.

Sekunowo, O. I., Adeosun, S. O., and Lawal, G. I. 2013. "Potentiostatic Polarisation Responses of Mild Steel in Seawater and Acid Environments". International Journal of Scientific \& Technology Research, 2, 10, 139145.

Sundjono dan Saefudin. 2014. "Pengaruh Temperatur dan pH Air Sadah Kalsium Sulfat terhadap Korosi pada Baja Karbon". Majalah Metalurgi, $29,1,41-50$.

Toloei, A., Atashin, S., and Pakshir, M. 2013. "Corrosion Rate of Carbon Steel Under Synergistic Effect of Seawater Parameters Including $\mathrm{pH}$, Temperature, and Salinity in Turbulent Condition". Corros Rev., 31, 6, 135144.

Uhliq, H. H., and Revie, R. W. (2008). Corrosion and Corrosion Control: An Introduction to Corrosion Science and Engineering, 4th ed. Canada: John Wiley \& Sons.

Umeozokwere, A. O., Mbabuike, I. U., Oreko, B. U., and Ezemuo, D. T. 2016. "Corrosion Rates and
Its Impact on Mild Steel in Some Selected Environments". Journal of Scientific and Engineering Research, 3, 1, 34-43.

Utomo, S. 2015. "Pengaruh Konsentrasi Larutan $\mathrm{NaNO}_{2}$ Sebagai Inhibitor Terhadap Laju Korosi Besi Dalam Media Air Laut". Jurnal Teknologi, 7, 2, 93-103.

Yuwei, L., Zhenyao, W., and Yinghua, W. 2019. "Influence of Seawater on The Carbon Steel Initial Corrosion Behavior". Int. J. Electrochem. Sci., 14, 1147-1162.

Zakowski, K., Narozny, M., Szocinski, M., and Darowicki, K. 2014. "Influence of Water Salinity on Corrosion Risk-The Case of The Southern Baltic Sea Coast". Environ Monit Assess, 186, 4871-4879. 